\title{
DE CRISES E MUDANÇAS
}

$\mathrm{C}$ onviver com crises e mudanças é parte do cotidiano. Com a vida institucional da Pensar a Prática, não tem sido diferente. A revista vem superando os primeiros obstáculos relacionados à expansão e nova fase marcada, entre outras questões, por sua indexação ao Lilacs, por sua periodicidade trimestral e pela avaliação qualis Capes que a reconheceu no extrato $\mathrm{B} 2$ no ano passado.

Esta nova fase, no entanto, foi caracterizada sobretudo pela intensificação do trabalho em todas as funções que caracterizam o processo editorial. No ano de 2012, recebemos 311 submissões de novos textos para avaliação, superando todas nossas expectativas, que já eram muito positivas, sobre a boa repercussão da revista junto à comunidade acadêmica. Mas a intensificação amplia as dificuldades constantes da tarefa editorial, criando situações de crise, ainda mais em um país como o Brasil e num campo como o da Educação Física, em que esta atividade não está consolidada e corretamente valorizada.

Em função dessas circunstâncias é que avaliamos como adequada a suspensão temporária de novas submissões. Ação que se mostrou necessária para "organizar a casa" e tomar medidas para contornar alguns problemas que já se delineavam. O volume de submissões nos trouxe problemas de ordem gerencial, agravando algumas questões e precipitando outras; desencadeando, no fim, medidas para o enfrentamento da situação.

As crises, por outra perspectiva, nos trazem possibilidades de crescimento. Com apoio da direção da Faculdade de Educação Física, a secretaria administrativa da revista ampliou seu número de equipamentos e profissionais, contando agora com dois servidores técnicoadministrativos concursados e com formação universitária em algumas das tarefas fundamentais para a qualidade da revista. Estamos, também, buscando ampliar a equipe de pareceristas, assim como a editorial, contando com editores especializados por seções, além de dois editores gerentes.

Mudança que se registra também com a passagem do professor Cleber Dias para a UFMG, mantendo, no entanto, sua colaboraçao editorial para com a Pensar a Prática. Da mesma forma, nos despedimos e agradecemos a colaboração editorial do professor Paulo Santia-

Pensar a Prática, Goiânia, v. 16, n. 1, p. 1-319, jan./mar. 2013

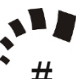


go da USP - Ribeirão Preto e damos as boas vindas ao professor Mário Hebling Campos da FEF/UFG.

É neste cenário de crises e mudanças que ora publicamos este volume, que conta com vinte textos, dos quais dois são artigos de revisão, quatro ensaios e uma resenha. O número mais expressivo, porém, é o de treze artigos originais de pesquisa, o que reflete outra forte característica das submissões feitas à revista, importante registro a ser feito. Os textos submetidos à Pensar a Prática vêem sendo gradativamente mais expressivaos em termos de artigos originais, mostrando uma nova característica da produção daqueles que veem, na revista, um veículo importante de comunicação científica e, provavelmente, também uma característica da produção do campo da Educação Física que se intensifica.

Outro resultado de crises e mudanças? O tempo dirá.

Ana Márcia Silva Cleber Dias Editores 